\title{
Limnological Study on two High Altitude Himalayan Ponds, Badrinath, Uttarakhand
}

\author{
Pramod Kumar $^{1, *}$, Ashwani Wanganeo ${ }^{1}$, Fozia Sonaullah ${ }^{1}$, Rajni Wangane ${ }^{2}$ \\ ${ }^{1}$ Department of Environmental Sciences and Limnology, Barkatullah University, Bhopal, 462026, India \\ ${ }^{2}$ Department of Zoology, Jay awanti Haksar Govt. P.G. College, Betul, M.P., India
}

\begin{abstract}
Present study has been done on two high altitude Himalayan ponds situated near the Badrinath temple, Uttarakhand (India). During the investigation physico-chemical and bio logical analysis (Phytoplankton \& Zooplankton) were carried out at two selected sites one in each pond. A total 131 species of phytoplankton and 51 species of zooplankton were encountered from both the ponds. Among phytoplankton, class Cyanophyceae was the most dominant whereas, among zooplankton Rotifera was the dominant class during the study period. Most of the phytoplankton and zooplankton species recorded from both the water bodies are indicators of higher trophic status. Physico-chemical features of ponds showed the nutrient rich water of both the ponds. Presence of various planktonic species and higher trophic status of both the ponds at high altitude showed the impact of high anthropogenic pressure as well as favourable environmental factors like temperature. Also, the impact of global warming on micro flora and fauna present in water bodies situated at high altitude has been discussed. Present study is preliminary work on these two ponds which will provide the baseline data for the further studies. Some further studies required to establish the importance of various environmental factors which are responsible for the growth of more planktonic species at higher altitudes.
\end{abstract}

Keywords Himalayan Ponds, Water Quality, Plankton Population, Trophic Status

\section{Introduction}

The aquatic habitats situated in mountains are some of the most sensitive indicators of environmental change[1]. Their high elevation leads to increased exposure to ultraviolet radiation as well as a shortened growing season that aggravates plankton populations due to both temperature and light limitations[2].

In order to assess the various limnological characteristics of the ponds, their physico-chemical and planktonological analys is was carried out. Study of planktonic population in relation to water chemistry provides the basic information of entire ecology of the pond.

Plankton are considered indicators of the different trophic status of a water body because of their specific qualitative features and their capacity to reproduce in large number under environmental conditions that are favourable to them[3] and they used for pollution surveillance[4,5-6].

Plankton are important part of aquatic life and good indicator of changes in water quality because they are strongly affected by environmental conditions and responds quickly to changes in environmental quality. Apart from

* Corresponding author:

pramodlimno2004@yahoo.com (Pramod Kumar)

Published online at http://journal.sapub.org/ije

Copyright (C) 2012 Scientific \& Academic Publishing. All Rights Reserved primary production, phytoplankton play an important role as food for herbivorous animals and act as biological indicators of water quality in pollution studies while, zooplankton occupy a vital role in the trophic structure of an aquatic ecosystem and play a key role in the energy transfer. Hence qualitative and quantitative assessments of plankton are of great importance.

The ponds are infested with macrophytic vegetation. The ponds receive glacial melt water besides runoff from the surrounding areas. These ponds are subject to high anthropogenic pressure by both local and tourists. The aim of this paper is to determine the overall role of anthropogenic pressure on these glacial fed ponds.

\section{Material and Methods}

Physico-chemical analysis of water samples was carried out following the standard methods as given in[7-8]. Water samples were directly collected from the surface of the pond for physico-chemical analysis and for the qualitative enumeration of planktonic population surface water samples were collected from different locations mainly from central part of the ponds. Plankton samples were filtered with the help of plankton net made of bolting silk of mesh size $20 \mu$ and concentrated samples were preserved with $1 \mathrm{ml}$ of Lugol's solution simultaneously in $100 \mathrm{ml}$ vials. The concentrated samples were examined under the inverted 
microscope and identification of plankton was done using the following taxono mic references [9-21].

The inter-relationships between the different planktonic communities present in both the ponds were calculated by Jaccard's similarity index[22]

$$
\mathrm{CC}_{\mathrm{i}}=\frac{\mathrm{C}}{(\mathrm{S} 1)+(\mathrm{S} 2)-\mathrm{C}}
$$

Where,

$\mathrm{CCi}=$ Jaccard coeffic ient of co mmunity similarity

$\mathrm{S}_{1}=$ Nu mber of species present in community 1

$\mathrm{S}_{2}=$ Nu mber of species present in community 2

$\mathrm{C}=$ Nu mber of species common in both the communities

\section{Study Area}

Both the selected ponds are situated at high altitude Himalayan region near Indo-Tibet boarder in Chamoli district of Uttarakhand. The place is popularly known as Badrinath (an important holly place of India). The Badrinath town is situated in the cold climatic condition of Garhwal hills, on the banks of the Alaknanda River at an elevation of 415 meters. The town lies between the Nar and Narayana mountain ranges and in the shadow of Nilkantha peak, most of the period it was covered by snow. The location and important features of both the ponds have been mentioned in Table 1 and Figure 1.

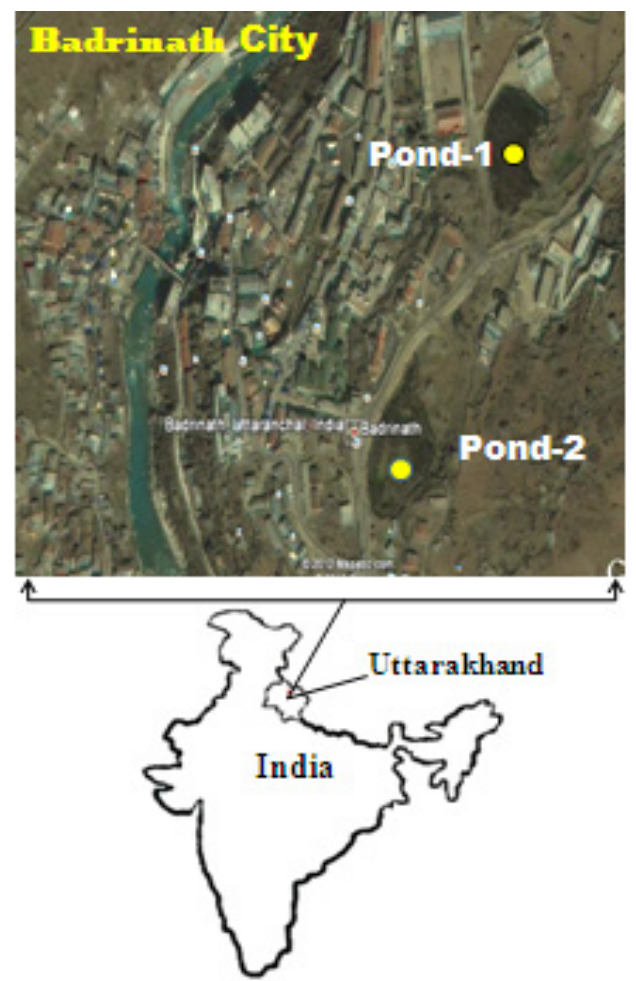

Figure 1. Showing sampling sites at both the selected ponds

\section{Results and Discussion}

The physico-chemical environment mainly controls the biological diversity[23, 24-25]. Physico-chemical features of the ponds are given in table 2 and planktonic flora and fauna are enlisted in tables 3 and 4 respectively.

During the present study air temperature of $22^{\circ} \mathrm{C}$ and water temperature of $18^{\circ} \mathrm{C}$ was observed at both the sampling sites. This optimum water temperature in both the ponds supports high biological population. The water colour of both the ponds was observed to be dark green due to the good growth of various algal species. The low transparency values of 36 $\mathrm{cm}$ and $40 \mathrm{~cm}$ was recorded in pond 1 and pond 2 respectively due to the dominance of green algae (table 2). Low transparency also indicates the eutrophic nature of pond waters[26-27]. The low transparency value in some of the high altitude Kashmir Himalayan water bodies has been attributed to the incoming silt from the catch ment[28-29].

Table 1. Some important feat ure of the selected ponds

\begin{tabular}{|l|c|c|}
\hline Features & Pond-1 & Pond-2 \\
\hline Location & Badrinath & Badrinath \\
\hline Type & Natural & Natural \\
\hline Latitude & $79^{\circ} 2939.19^{\prime \prime} \mathrm{E}$ & $79^{\circ} 29^{\prime} 43.25^{\prime \prime} \mathrm{E}$ \\
\hline Longitude & $30^{\circ} 4435.54^{\prime \prime} \mathrm{N}$ & $30^{\circ} 44^{\prime} 42.30^{\prime \prime} \mathrm{N}$ \\
\hline Altitude (m) & 3,415 & 3,422 \\
\hline Maximum length (m) & 144 & 92 \\
\hline Minimum width (m) & 62 & 85 \\
\hline Maximum depth (m) & 1 & 1.5 \\
\hline Average depth (m) & 0.5 & 0.5 \\
\hline Source of water & Rain water, Ice melts & $\begin{array}{c}\text { Rain water, } \\
\text { Ice melts }\end{array}$ \\
\hline
\end{tabular}

Table 2. Import ant physico-chemical characteristics the Ponds

\begin{tabular}{|l|c|c|}
\hline Parameters & Pond-1 & Pond-2 \\
\hline Air temperature $\left({ }^{\circ} \mathrm{C}\right)$ & 22 & 22 \\
\hline Water temperature $\left({ }^{\circ} \mathrm{C}\right)$ & 18 & 18 \\
\hline Depth $(\mathrm{m})$ & 1 & 1.5 \\
\hline Transparency $(\mathrm{cm})$ & 36 & 40 \\
\hline $\mathrm{pH}$ & 8.1 & 7.9 \\
\hline TDS $(\mathrm{ppm})$ & 470 & 510 \\
\hline Conduct ivity $\left(\mu \mathrm{S} / \mathrm{cm}^{2}\right)$ & 660 & 650 \\
\hline Free $\mathrm{CO}_{2}(\mathrm{mg} / \mathrm{l})$ & 4.6 & 5.2 \\
\hline Dissolved oxygen $(\mathrm{mg} / \mathrm{l})$ & 8.4 & 8.8 \\
\hline Ph. alkalinity $(\mathrm{mg} / \mathrm{l})$ & $\mathrm{Absent}$ & $\mathrm{Absent}$ \\
\hline Total alkalinity $(\mathrm{mg} / \mathrm{l})$ & 116 & 120 \\
\hline Chloride $(\mathrm{mg} / \mathrm{l})$ & 212 & 232 \\
\hline Total hardness $(\mathrm{mg} / \mathrm{l})$ & 130 & 168 \\
\hline Calcium hardness $(\mathrm{mg} / \mathrm{l})$ & 44 & 56 \\
\hline Mg. content $(\mathrm{mg} / \mathrm{l})$ & 20.8 & 27 \\
\hline Orthophosphate $(\mathrm{mg} / \mathrm{l})$ & 0.056 & 0.049 \\
\hline Nitrate $(\mathrm{mg} / \mathrm{l})$ & 0.38 & 0.43 \\
\hline
\end{tabular}

Alkaline $\mathrm{pH}$ of 8.1 units (pond 1) and 7.9 units (pond 2) indicating productive nature of pond waters. Free $\mathrm{CO}_{2}$ recorded a value of $4.6 \mathrm{mg} / \mathrm{l}$ to $5.2 \mathrm{mg} / 1$ in pond 1 and pond 2 respectively. Phenolphthalein alkalinity was absent in both the ponds. Total alkalinity of $116 \mathrm{mg} / 1$ and $120 \mathrm{mg} / 1$ was recorded for pond 1 and pond 2 respectively. Water bodies having total alkalinity above $50 \mathrm{mg} / 1 \mathrm{can}$ be considered productive in nature[30] (table 2). TDS value of $470 \mathrm{ppm}$ and $510 \mathrm{ppm}$ for pond 1 and 2 respectively, indicate regular interference from respective catchment area. The high specific conductivity values of $660 \mu \mathrm{S} / \mathrm{cm}$ and $650 \mu \mathrm{S} / \mathrm{cm}$ signify high amount of anthropogenic pressure[31-27]. 
Water bodies having conductivity values greater than 500 $\mu \mathrm{S} / \mathrm{cm}$ are considered as eutrophic in nature[32]. Chloride content of $212 \mathrm{mg} / 1$ and $232 \mathrm{mg} / \mathrm{l}$ respectively again signify the impact of anthropogenic pressure (table 2). A value of 8.4 $\mathrm{mg} / \mathrm{l}$ and $8.8 \mathrm{mg} / \mathrm{l}$ of Dissolved oxygen in surface waters of both the ponds suggested good growth of autotrophs.

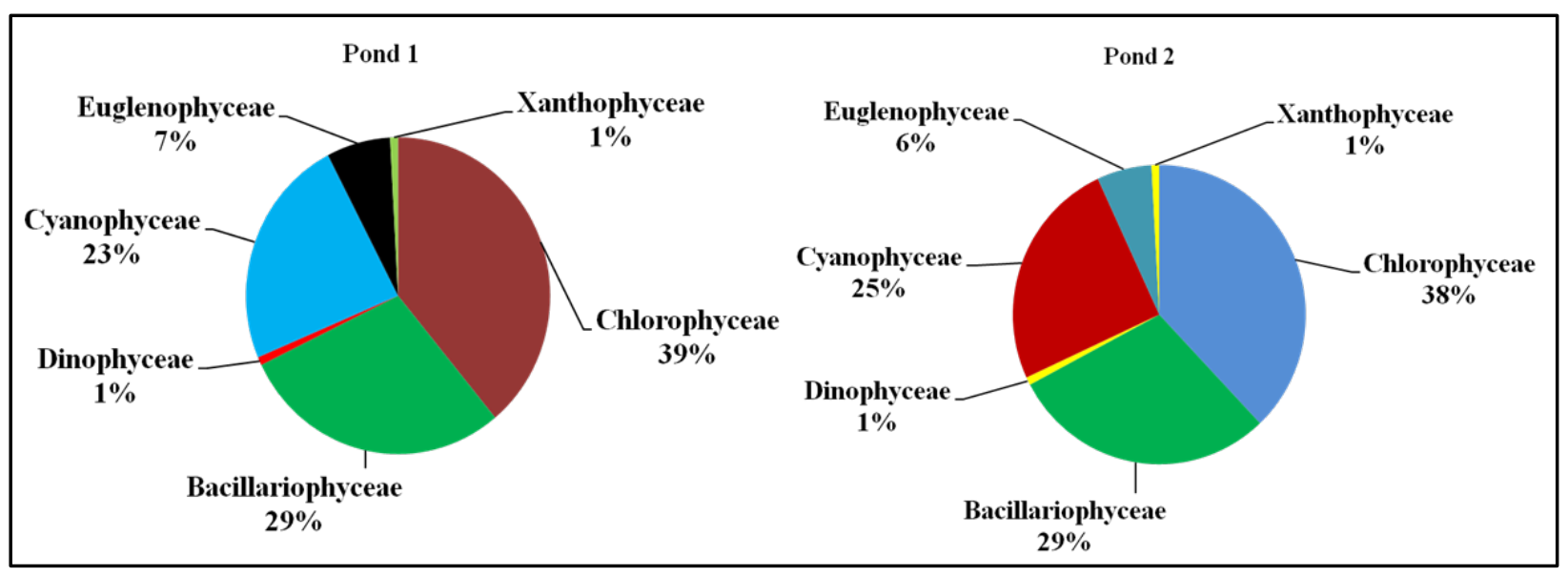

Figure 2. Classwise percentage composition of Phytoplankt on population in both the ponds

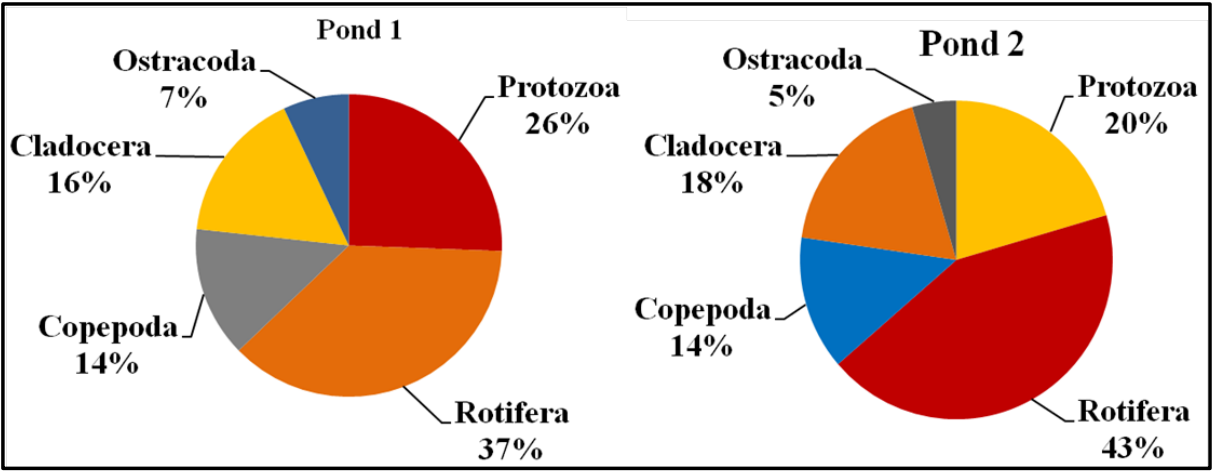

Figure 3. Classwise percentage composition of Zooplankton population in both the ponds
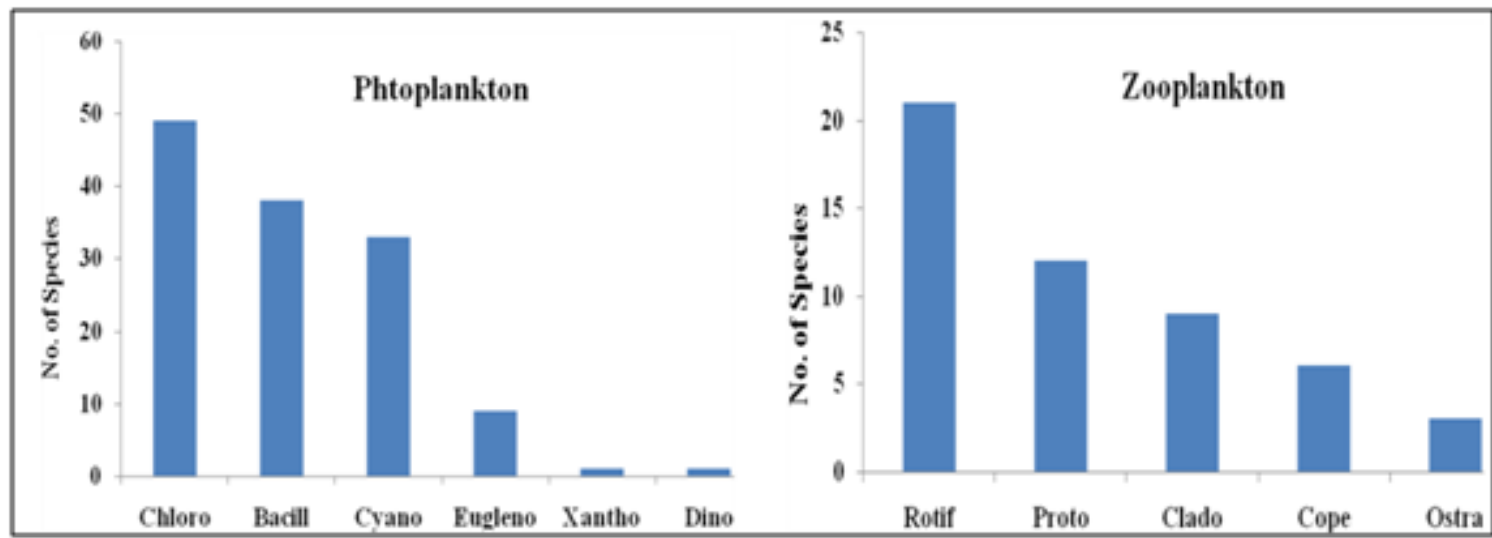

Figure 4. Overall species composition of Phytoplankt on and Zooplankton recorded from both the ponds

Table 5. Species contribution of different planktonic groups in both the selected Pond

\begin{tabular}{|c|c|c|c|c|c|}
\hline Phytoplankton & Pond 1 & Pond 2 & Zooplankton & Pond 1 & Pond 2 \\
\hline Chlorophyceae & 46 & 44 & Rotifera & 16 & 19 \\
\hline Bacillariophyceae & 34 & 34 & Protozoa & 11 & 9 \\
\hline Cyanophyceae & 28 & 29 & Cladocera & 7 & 8 \\
\hline Euglenophyceae & 8 & 7 & Copepoda & 6 & 6 \\
\hline Dinophyceae & 1 & 1 & Ostracoda & 3 & 2 \\
\hline Xanthophyceae & 1 & 1 & & & \\
\hline Total & 118 & 116 & Total & 43 & 44 \\
\hline
\end{tabular}


Total hardness values of $130 \mathrm{mg} / 1$ and $168 \mathrm{mg} / 1$ was observed in pond 1 and pond 2 respectively. On the basis of hardness values water of both the ponds is of hard water type. Calcium hardness of $44 \mathrm{mg} / 1$ and $56 \mathrm{mg} / 1$ and Magnesium contents $20.8 \mathrm{mg} / 1$ and $27 \mathrm{mg} / 1$ recorded for pond 1 and pond 2 respectively suggest that both the ponds are Calcium rich. The water bodies rich in Calcium and Magnesium ions have thick population of algae[33]. In the present study $0.056 \mathrm{mg} / 1$ (pond 1) and $0.049 \mathrm{mg} / 1$ (pond 2) of Orthophosphate; and $0.38 \mathrm{mg} / 1$ (pond 1) and $0.43 \mathrm{mg} / 1$ (pond 2) of Nitrate values were recorded (table 2). These values of Orthophosphate and Nitrate indicated the healthy mesotrophic status of pond waters [34].

Besides physico-chemical features, observations on changes in planktonic diversity are generally considered a necessity in evaluating the impact of environ mental changes on an aquatic system, especially phytoplankton that show changes with the changes in the environmental factors [35].

Plankton are very significant tool for observing the continuous changes in the environmental conditions at higher altitudes. They are the most sensitive micro organisms that respond quickly to any change in the ecological condition. Hence, they can be used as ecological indicators. They are able to grow at higher altitudes as compared to other macro flora and fauna.

During the present period of investigation, a total of 118 and 116 phytoplankton species have been recorded from pond 1 and pond 2 respectively (table 3 ).

From the pond 1, 46 species (39\%) of Chlorophyceae; 34 $(29 \%)$ species of Bacillariophyceae; $28(23 \%)$ species of Cyanophyceae; 8 (7\%) species of Euglenophyceae and 1 (1\%) specie each of Dinophyceae and Xanthophyceae were recorded (table $5 \&$ figure 2).

In the pond 2, Chlorophyceae contributed 44 species $(38 \%)$ of the total phytoplankton population followed by Bacillariophyceae 34 species (29\%); Cyanophyceae 29 species (25\%) and Euglenophyceae 7 species (6\%) respectively. Class Dinophyceae and Xanthophyceae contributed 1specie (1\%) each towards the total phytoplankton respectively (table $5 \&$ figure 2 )

Table 3. Composition of Phytoplankton Population of Badrinath pond

\begin{tabular}{|l|c|c|}
\hline Chlorophyceae & Pond-1 & Pond-2 \\
\hline Botryococcus braunii & + & + \\
\hline Actinastrum hantzschii & + & + \\
\hline Ankistrodesmus falcatus & + & + \\
\hline Ankistrodesmus sp. & + & - \\
\hline Calothrix sp & + & + \\
\hline Chlorella sp. & + & + \\
\hline Chlorella vulgaris & + & + \\
\hline Chlorococcum sp. & + & + \\
\hline Closteriopsis sp. & + & + \\
\hline Closterium parvulum & + & + \\
\hline
\end{tabular}

\begin{tabular}{|c|c|c|}
\hline Coelastrum microporum & + & + \\
\hline Coelastrum $\mathrm{sp}$. & + & + \\
\hline Cosmarium bengalicum & + & + \\
\hline Cosmarium depressum & + & + \\
\hline Cosmarüum margaritatum & + & + \\
\hline Crucigenia quadrata & + & + \\
\hline Elkatothrix sp. & - & + \\
\hline Euastrum sp. & + & + \\
\hline Gloeocystis sp. & + & + \\
\hline Gloeotrichia sp. & + & + \\
\hline Gonium sp. & + & + \\
\hline Mougeotia sp. & + & + \\
\hline Oocystis sp. & + & + \\
\hline Oocystis crassa & + & + \\
\hline Pandorina cylindricum & + & - \\
\hline Pediastrum duplex & + & + \\
\hline Pediastrum simplex & + & + \\
\hline Pediastrum tetras & + & + \\
\hline Scenedesmus abundans & + & + \\
\hline Scenedesmus armatus & + & + \\
\hline Scenedesmus bijugatus & + & + \\
\hline Scenedesmus dimorphos & + & + \\
\hline Scenedesmus obliquus & + & + \\
\hline Scenedesmus quadricauda & + & + \\
\hline Schroderia setigera & + & - \\
\hline Selenastrum westii & + & + \\
\hline Spirogyra porticalis & + & + \\
\hline Staurastrum sp. & + & + \\
\hline Stigeoclonium sp. & + & - \\
\hline Tetraedron gracile & + & - \\
\hline Tetraedron minimum & + & + \\
\hline Tetraedron muticum & - & + \\
\hline Tetraedron proteforme & + & + \\
\hline Tetraedron trigonum & + & + \\
\hline Tetraedron trilobatum & - & + \\
\hline Ulothrix sp. & + & + \\
\hline Ulothrix zonata & + & + \\
\hline Westella $\mathrm{sp}$. & + & + \\
\hline Westell linearis & + & + \\
\hline \multicolumn{3}{|l|}{ Bacillarioph yceae } \\
\hline Achnanthes lanceolata & + & + \\
\hline Achnanthesminutissima & + & + \\
\hline
\end{tabular}




\begin{tabular}{|c|c|c|}
\hline Amphora ovalis & + & + \\
\hline Anomoeoneis sphaerophora & + & + \\
\hline Ceratonies arcus & + & + \\
\hline Cocconeis sp. & + & + \\
\hline Cocconeis placentula & - & + \\
\hline Cyclotella sp. & + & + \\
\hline Cymbella affinis & + & + \\
\hline Cymbella ventricosa & + & + \\
\hline Cymbella tumida & + & + \\
\hline Diploneis sp. & + & + \\
\hline Epithemia sp. & + & - \\
\hline Eunotia sp. & + & + \\
\hline Fragillaria sp. & + & + \\
\hline Fragilaria intermedia & + & + \\
\hline Gomphonema lanceolatum & + & + \\
\hline Gomphonema lucas rankala & + & - \\
\hline Gomphonema montanum & + & + \\
\hline Gomphonema sphaerophonum & + & + \\
\hline Melosira granulata & + & + \\
\hline Navicula sp. & + & + \\
\hline Navicula cryptocephala & + & + \\
\hline Navicula grimmii & + & - \\
\hline Navicula rostellata & + & + \\
\hline Navicula subrhyncocephalas & + & + \\
\hline Navicula subtilissima & + & + \\
\hline Navicula tumida & - & + \\
\hline Nitzschia sp. & + & + \\
\hline Nitzschia capitellata & - & + \\
\hline Nitzschia palea & + & + \\
\hline Nitzschia sigma & + & + \\
\hline Pinnularia sp. & + & + \\
\hline Pinnularia interrupta & + & + \\
\hline Pleursigma sp. & + & + \\
\hline Synedra ulna & + & + \\
\hline Synedra ulna var. biceps & + & + \\
\hline Tabillaria sp. & + & + \\
\hline \multicolumn{3}{|l|}{ Cyan ophyceae } \\
\hline Anacystis sp. & + & + \\
\hline Anabaena naviculoides & + & + \\
\hline Anabaena spiroides & + & + \\
\hline Aphanocapsa muscicola & + & + \\
\hline Aphanocapsa montana & - & + \\
\hline
\end{tabular}

\begin{tabular}{|c|c|c|}
\hline Aphanocapsa koordesii & + & + \\
\hline Aphanothece saxicola & + & + \\
\hline Aphanizomenon flos-aquae & + & - \\
\hline Arthrospira platensis & + & + \\
\hline Chroococcus sp. & + & + \\
\hline Cylindrospermum sp. & + & + \\
\hline Cylindrospermum stagnale & + & + \\
\hline Gloeocapsa sp. & + & + \\
\hline Gloeocapsa atrata & - & + \\
\hline Limnothrix lautebornii & + & + \\
\hline Lyngbya martensiana & + & + \\
\hline Lyngbya versicolor & + & - \\
\hline Merismopedia tenuissima & - & + \\
\hline Microcystis aenginosa & + & + \\
\hline Microcystisflos-aquae & + & + \\
\hline Nostoc commune & + & + \\
\hline Oscillatoria curviceps & - & + \\
\hline Oscillatoria limnetica & + & - \\
\hline Oscillatoria limosa & + & + \\
\hline Oscillatoria peromata & + & + \\
\hline Oscillatoria princes & + & + \\
\hline Oscillatoria pseudogeminata & + & + \\
\hline Oscillatoria rubescens & + & + \\
\hline Oscillatoria subbrevis & + & + \\
\hline Phomidium tenue & + & + \\
\hline Raphidiopsis sp. & + & + \\
\hline Spinulina major & - & + \\
\hline Spinulina laxissima & + & + \\
\hline \multicolumn{3}{|l|}{ Euglenoph yceae } \\
\hline Euglena sp. & + & + \\
\hline Euglena acus & + & + \\
\hline Euglena vagans & + & - \\
\hline Euglena proxima & + & + \\
\hline Euglenomorpha sp. & + & + \\
\hline Lepocinclis sp. & + & + \\
\hline Trachelomonas armata & + & + \\
\hline Trachelomonas playfairii & - & + \\
\hline Trachelomonas oblonga & + & - \\
\hline \multicolumn{3}{|l|}{ Dinophyceae } \\
\hline Ceratium sp. & + & + \\
\hline \multicolumn{3}{|l|}{ Xan thophyceae } \\
\hline Tribonema sp. & + & + \\
\hline
\end{tabular}


The class wise dominance of phytoplankton population in both the ponds was same. Among phytoplankton, class Chlorophyceae showed its maximum dominance in both the selected ponds followed by Bacillariophyceae, Cyanophyceae, Euglenophyceae, Dinophyceae and Xanthophyceae (table 5). During the investigation it was observed that both the ponds were infested with macrophytic vegetation besides algal blooms in the surface waters. Maximum planktonic diversity was observed nearby macrophytic vegetation in the Himalayan water bodies [36]. The species recorded from the Badrinath ponds reflected higher anthropogenic impact supporting good growth of planktonic flora and fauna.

Generally, Bacillariophyceae are found as do minant group in temperate water bodies because diatoms are able to grow under the conditions of weak light and low temperature which are less suitable for the other phytoplankton groups[35-37]. But, during the present investigation Chlorophyceae was recorded as dominant among all the phytoplankton groups on account of relatively high temperature and nutrient condition.

Most dominant genus of phytoplankton encountered from both the ponds was Scenedesmus, Tetraedron, Cymbella, Gomphonema, Navicula, Nitzschia, Oscillatoria, Aphanocapsa, Euglena and Trachelomonas (table 3). Each of these genus are known to indicate polluted waters [38].

Among Phytoplankton, Elkatothrix sp., Tetraedron muticum and Tetraedron trilobatum of Chlorophyceae; Cocconies placentula, Navicula tumida, Nitzschia capitellata of Bacillariophyceae; Aphanocapsa Montana, Gloeocapsa atrata, Merismopedia tenuissima, Oscillatoria curviceps, Spirulina major of Cyanophyceae; Trachelomonas playfairii of Euglenophyceae were not recorded from pond 1, whereas, Ankistrodesmus sp., Pandorina cylindricum, Schroderia setigera, Staurastrum sp., Tetraedron gracile of Chlorophyceae; Epithemia sp., Gomphonema lucas rankala, Navicula grimmii of Bacillariophyceae; Aphanizomenonflosaquae, Lyngbya versicolor, Oscillatoria limnetica of Cyanophyceae and Trachelomonas oblonga of Euglenophyceae were absent in pond 2 (table 3 ).

During the present study a total of 39 and 40 zooplankton species were recorded from pond 1 and pond 2 respectively. During the present investigation Rotifera contributed 16 species $(37 \%)$ of the total zooplankton population in the pond 1 followed by Protozoa 11 species (26\%); Cladocera 7 species (6\%); Copepoda 5 species (14\%) and Ostracoda 3 species (7\%) respectively (figure 3 and table 4). In pond 2 Rotifera again dominated the group with 19 species (43\%) followed by Protozoa 9 species (20\%); Cladocera 8 species $(18 \%)$; Copepoda 5 species $(14 \%)$ and Ostracoda 2 species (5\%) (figure 3 and table 4$)$.

An overall dominance of Rotifera in both the ponds under present investigation indicates that the ponds are under the influence of eutrophication. In various temperate water bodies predominance of Rotifera has been reported by various workers [39-46].
Rotifer species viz., Asplanchna brightwelli, Brachionus angularis, Brachionus bidentata, Brachionus calyciflorus, Brachionus caudatus, Brachionus forficula, Brachionus falcatus, Cephlodella gibba, Cephlodella catelina, Filinia longiseta, Keratella cochlearis, Keratella tropica, Keratella quadrata, Lecane sp., Lecane closterocera, Lecane luna and Polyarthra vulgaris recorded in the present investigation have also been reported from a highly eutrophic pond[27] and most of these species have been considered as indicators of eutrophication [29, 36,42-46].

Table 4. Composition of Zooplankton Population of Badrinath pond

\begin{tabular}{|l|c|c|}
\hline Name of the Taxa & Pond 1 & Pond 2 \\
\hline Protoz oa & & \\
\hline Arcella discoids & + & + \\
\hline Arcella vulgaris & + & + \\
\hline Centropyxis ecornis & + & + \\
\hline Difflugia cum inata & + & + \\
\hline Difflugia sp. & + & + \\
\hline Glenodinium sp & + & + \\
\hline Oxytricha sp. & + & + \\
\hline Paramoecium sp. & + & - \\
\hline Tardigrade sp & + & + \\
\hline Vampyrella sp & + & + \\
\hline Vorticella sp & + & + \\
\hline Rotife ra & + & + \\
\hline Asplanchna brightwelli & + & + \\
\hline Brachionus angularis & + & + \\
\hline Brachionus bidentata & + & + \\
\hline Brachionus calyciflons & + & + \\
\hline Brachionus caudatus & + & + \\
\hline Brachionus forficula & + & + \\
\hline Brachionus falcatus & + & + \\
\hline Bosmina sp. & + & + \\
\hline Cephlodella gibba & + & + \\
\hline Cephlodella catelina & + & + \\
\hline Filinia sp. & + & + \\
\hline Filinia longiseta & + & + \\
\hline Keratella cochlearis & + & + \\
\hline Keratella tropica & + & + \\
\hline Keratella quadrata & + & + \\
\hline Lecane luna & + & + \\
\hline & + & + \\
\hline Lontyla (Lecane) & + & + \\
\hline
\end{tabular}




\begin{tabular}{|l|c|c|}
\hline Phyllodina sp & + & + \\
\hline Polyarthra vulgaris & + & + \\
\hline Testudinella sp & + & + \\
\hline Copepoda & & \\
\hline Arctodiaptomus dorsalis & + & + \\
\hline Cyclops sp. & + & + \\
\hline Diaptomus sp. & + & + \\
\hline Mesocyclops hyalinus & + & + \\
\hline Nauplius larvae & + & + \\
\hline Thermocylops crassus & + & + \\
\hline Cladocera & + & + \\
\hline Alona intermediate & + & + \\
\hline Moina branchiata & + & + \\
\hline Bosmina longirostris & + & + \\
\hline Ceriodaphnia puchella & + & + \\
\hline Chydonus sphaericus & + & + \\
\hline Macrothrix rosea & + & + \\
\hline Daphnia pulex & + & + \\
\hline Diaphanosoma excisum & + & + \\
\hline Pleuroxus denticulate & + & + \\
\hline Ostracoda & + & + \\
\hline Stenocyprismalcomsoni & + & + \\
\hline Cyprinotua glaucus & + & + \\
\hline Stenocypris sp. & + & + \\
\hline
\end{tabular}

Protozoa recorded as second dominant class in both selected ponds was mostly represented by Arcella discoids, Arcella vulgaris, Centropyxis ecornis, Difflugia cuminata, Difflugia sp., Paramoecium sp. and Tardigrade sp. These species are indicators of higher trophic status by[24, 27, 47 $-49]$.

In general low Cladocera and Copepod species were recorded in both the ponds. Among Cladoceran, all the species listed in table 5 grow well in nutrient rich waters [7, 24-27, 36, 46]. All the species belonging to Copepods namely Arctodiaptomus dorsalis, Cyclops sp.,Diaptomus sp., Mesocyclops hyalinus, Nauplius larvae, Thermocylops crassus; and three species of Ostracoda viz., Cyprinotus glaucus and Stenocypris malcomsoni and Stenocypris sp. were reported as pollution indicators [24-27,46,50-52]. Arctodiaptomus dorsalis dominates the crustacean zooplankton in moderately productive water bodies [53] and cannot survive under conditions of low food concentrations [54]. In water bodies at higher latitudes and altitudes, Arctodiaptomus dorsalis may appear mainly in the warmer seasons. It is often dominant in eutrophic water bodies [55-56].

Among Zooplankton, Brachionus calyciflorus,Brachionu $s$ falcatus, Cephlodella gibba, Filinia longiseta, Lecane closterocera of Rotifera; and Alona intermediate and Chydorus sphaericus of Cladocera were not recorded in pond 1, whereas, Vorticella sp., Paramoecium sp. of Protozoa; Brachionus bidentata, Bosmina sp., Keratella quadrata of Rotifera; Pleuroxus denticulate of Cladocera and Stenocypris sp., of Ostracoda was not recorded from pond 2 (table 4).

Jaccard's similarity index showed that the species belongs to Dinophyceae and Xanthophyceae are $100 \%$ similar at both the sites while the species belonged to Bacillariophyceae showed $89 \%$ similarity followed by Chlorophyceae $84 \%$, Cyanophyceae $78 \%$ and Euglenophyceae $67 \%$ between both the ponds. Among zooplankton Copepoda showed 100\% similarity followed by $82 \%$ of Protozoa and $67 \%$ each of Rotifera, Cladocera and Ostracoda between both the ponds (table 6).

Table 6. Jaccard similarity index for different planktonic groups of both the ponds

\begin{tabular}{|l|c|l|l|}
\hline \multicolumn{2}{|c|}{ Phytoplankton } & \multicolumn{2}{c|}{ Zooplankton } \\
\hline Chlorophyceae & 0.84 & Protozoa & 0.82 \\
\hline Bacillariophyceae & 0.89 & Rotifera & 0.67 \\
\hline Dinophyceae & 1.00 & Copepoda & 1.00 \\
\hline Cyanophyceae & 0.78 & Cladocera & 0.67 \\
\hline Euglenophyceae & 0.67 & Ostracoda & 0.67 \\
\hline Xanthophyceae & 1.00 & & \\
\hline
\end{tabular}

The overall qualitative class wise species contribution of phytoplankton and zooplankton of both ponds have been shown in figure 4 . The maximum contribution was made by Chlorophyceae and minimum by Dinophyceae among phytoplankton while Rotifera contributed maximum and Ostracoda minimum among zooplankton population.

The presence of more diversity of planktonic flora and fauna at high altitudes showed the favourable environmental conditions for their growth. Both the ponds are situated at base of high mountains and during the high precipitation the nutrient rich runoff settled in the ponds and increased the trophic levels and creates the favourable conditions for the growth of planktonic population. The changes in physico-chemical parameters led to increase in diversity of planktonic flora and fauna in high altitude Himalayan water bodies[57]. Besides the anthropogenic pressure, impact of global climate changes also supports the microscopic life to grow in aquatic systems situated at higher altitude.

\section{Conclusions}

The biological as well as physico-chemical result of both the ponds indicate the significant role of anthropogenic activity for growth of planktonic diversity and their distribution. Generally, water bodies situated at higher altitudes are oligotrophic and do not support the diverse groups of planktonic flora and fauna. But species recorded during present investigation are the classic indicators of a shift from oligotrophic (Low productivity) conditions to 
eutrophic (High productivity) conditions of both the ponds. However, the variation in some planktonic species in these ponds suggest the need of further studies to establish the importance of various environmental factors, their seasonal fluctuations that produce a collective effect on the nature and distribution of freshwater mic roscopic life at higher altitudes. Present study is first hand work on these two small ponds which will provide the baseline data for the further studies.

\section{REFERENCES}

[1] Williamson C. E., Dodds W., Kratz T. K. \& Palmer M. A. Lakes and streams as sentinels of environmental change in terrestrial and atmospheric processes. Frontiers in Ecology and the Environment, 2008, 6:247-254.

[2] Sommaruga R. The role of solar UV radiation in the ecology of alpine lakes. Journal of Photochemistry and Photobiology, 2001, B: Biology 62: 35-42.

[3] Vollenweider, R.A. Scientific fundamentals of the eutrophication of lakes and flowing waters, with particular reference to nitrogen and phosphorus as factors in eutrophication OECD. Paris. Tech Report DA 515C116827, $1968,250 \mathrm{p}$.

[4] Prescott, G.W. Some relationship of phytoplankton to limnology and aquatic biology. Publ. Amer. Assoc. Adv. Sci. publ., 1939, 10, 65-78.

[5] Lund, J.W.G. Phytoplankton from some lakes of northern Saskatchewan and from Great Salve Lake. Can. J. Botany, 1962, 40: 1499-1514.

[6] Brook, A.J. Planktonic algae as indicators of lake type with special reference to the Desmidiaceae. Limnol. Oceanogr. (1965), 10, 403-211.

[7] Adoni A. D. Work book on limnology. Pratibha Publishers, Sagar, (1985), 1-126.

[8] APHA. Standard methods for the examination of the water and waste water. 20th addition. American Public Health (1998).

[9] Ward H.B. and Whipple G.C. Freshwater biology. (2nd Ed) John Willey and Sons Inc. New York, 1959.

[10] Desikacharya T.V. Book of Cyanophyta. ICAR, New Delhi, Publication, 1958.

[11] Needham J.G. and Needham P.R. A guide to the study of fresh water biology. Publishers-Holden -Day, Inc., San Francisco, U.S.A., 1962, pp: 107.

[12] G.W. The Fresh Water Algae. Brown Company Publishers, Dubuque, Lowa, 1973.

[13] Pennak, R. W. Freshwater invertebrates of United States 2nd Edn. John Willey Sons Inc., New York, 1978.

[14] Victor, R. and Fernando, C. H. The fresh water Ostracoda (Crustacea: Ostracoda) of India. Records of the zoological survey of India, 1979, 74(2) 147-242.
[15] Michael, R.G. \& Sharma, B.K. INDIAN CLADOCERA. (Crustacea: Branchiopoda: Cladocea). Fauna of India and adjacent countries. Zool. Sur. India, 1988, p 261.

[16] Edmondson, W. T. Freshwater biology. 2nd Ed. John Wiley \& Sons, New York, U.S.A., 1959.

[17] Battish, S.K. Freshwater zooplankton of India. Oxford and IBH Publishing Co. Ltd. New Delhi, 1992.

[18] Reddy, Y.R. Copepoda: Calanoda: Diap tomidae: Guide to the identification of the mio-inverte -brates of the continental waters of the world, 1994, Vol.5 SPB Publishers, The Hague, Netherland.

[19] Sinha S. and Naik M.L. Phytoplankton and Macrophytes in the ponds of Raipur city area, M.P. Pub. Ravi shanker Shucla University, Raipur, M.P., 1997, pp-164.

[20] Sharma, B. K. Freshwater Rotifers (Rotifera: Eurotatoria) Zoological Survey of India. State Fauna Series 3, Fauna of West Bengal, 1999, Part 11: 341-468.

[21] Dhanapathi, M.V.S.S.S.. Rotifers from Andhra Pradesh, India-III. Hydrobiologia, 2003, 48(1): 9-16.

[22] Jaccard, P. "Étude comparative de la distribution florale dans une portion des Alpes et des Jura". Bulletin de la Société Vaudoise des Sciences Naturelles, 1901, 37: 547-579

[23] S. K., George M.P., Saxena R., Johri M. and Shrivsatava M. Seasonal variation in the limno chemical characteristics of Mansarovar reservoir of Bhopal. In: S.R. Mishra and Saksena, D.N.(eds), Aquatic Ecology, 1992, Ashish Publishing House, New Delhi, pp 275-292.

[24] Agarkar M.S., Goswami H.K., Kaushik S., Mishra S. N., Bajpai A.K. and Sharma U.S.. Biology, conservation and management of Bhoj Wetland 1. Upper Lake Ecosystem in Bhopal. Bionature, 1994, 14 (2), pp 1-119.

[25] Wanganeo A., Wanganeo R. and Pani S. Summer dissolved oxy gen regimes in tropical Vindhyan Lake in relation to its conservation strategy. Strategy Bionature, 1997, 17(1): 7-11.

[26] Lee G.F., Jones R. A., and Rast W. Alternative approach to trophic status classification for water quality management. Occasional paper no. 66. Dept. of Civil Eng. Env. Eng. Progress. Colorado, State University fort Collins Co., 1981.

[27] Kumar P., Wanganeo A. and Sonaullah F. A Preliminary Limnological Study on Shershah Suri Pond, Sasaram, Bihar. Asian J. Exp. Sci. 2010, Vol. 24, No. 2, 219-226.

[28] Bamforth S. Ecological studies on the planktonic Protozoa of a small artificial pond. Limnology of Oceanography, 1958, Vol. 3, pp. 398-412.

[29] Wanganeo A., Raina R. and Zutshi D.P. Limnological studies on dimictic Himalayan Lake. Rec. Adv. Fish Ecol. Lim. Eco-conserv. 1996, IV: 37-54

[30] Moyle J.B. Some indices of lake productivity trends. American Fisheries Society, 1946, 76, pp. 322-334.

[31] Raina R., Wanganeo, A., Fozia S. and Pramod K. Variation in summer Limnological characteristics of Bodsar wetland over a period of more than two decades. J. Himalayan Ecol. Sustian. Dev., 2009, Vol 4. 
[32] Olsen S. Aquatic plants and hydrospheric factor, I. Aquatic plants in Switzerland, Arizona. J. Sevensk. Botanisk Tidskriff, 1950, 44: 1-34.

[33] Kaul V., Trisal C. L. and Handoo J. K. Distribution and production of macrophytes in some water bodies of Kashmir. In Glimpses of Ecology, 1978, Eds. J.S. Singh \& B. Gopal. Praksh Publ. Jaipur. 592 pp.

[34] Wetzel R.G. Limnology. W.B. Saunders Co. Philadelphia, 1975, pp: 743.

[35] Mir A. R., Wanganeo A., Yousuf A. R. and Wanganeo R. Plankton dynamics in relation to fish in Wular lake of Kashmir. Poll. Res. 2007, 26 (4): 733-743.

[36] Wanganeo A. and Wanganeo R. Variation in Zooplankton population in two morphologically dissimilar rural lakes in Kashmir Himalay a. Nat. Acad. Sci. 2006, 76 (B) III. 222-239.

[37] Wanganeo A. and Wanganeo R. Algal population in valley lakes of Kashmir Himalaya. Arch. Hydrobiol., 1991, 131(2): 219-233.

[38] Raina R., Subla B. A. and Zutshi D.P. Water quality and plankton of Jhelum River. Int. J. Ecol. Environ. Sci. 1982, 8: $11-17$.

[39] Vass K.K., Wanganeo A., Raina H.S., Zutshi D.P. and Wanganeo R. Summer limnology and fisheries of high mountain lakes of Kashmir Himalayas. Arch.Hydrobiol, (1989): 114-4, 606-619.

[40] Wanganeo A. Phytoplankton photosynthesis, nutrient dynamics \& trophic status of Manasbal Lake, Kashmir. 1980, Ph.D. Thesis, Kashmir University (Unpublished).

[41] Raina, R. Plankton dynamics and Hydrobiology of Bod-Sar Lake, Kashmir. 1981, Ph. D. Thesis. Kashmir University, Kashmir, (Unpublished).

[42] Thunmark S. Die Abwassserfrage der vaxijaseen in hydrobiologischer Beleuchtung, Grundzuge in der regination planktologie van sudschweden. Medd. Lunds. Univ. Limnol. Inst., 1945, 4: 239.

[43] Berzins B. Zye limnologie der seen sudosttettlands. Schweiz.Z. Hydrol.1949, 11: 583-607.

[44] Arora H.C. Rotifers as indicators of trophic nature of environments. Hy drobiol. 1966, 27: 46-49.

[45] Sharma B. K. Assessment of pollution indicators in Indian rotatoria. J. Meghalaya Sci. 1986, X., 47-49.
[46] Kulshrestha S. K., Adholia U.N., Bhatnagar A., Khan A.A., Saxena M. and Baghail M. Studies on pollution on river Kshipra:Zooplankton in relation to water quality. Int. J. Ecol. Env. Sci. 1989, 15:27-36.

[47] David A. and Roy S. Studies on the pollution of the river Dana, North Bihar by Sugar and Distillery wastes. Environ. Hlth. 1966, 8: 6-35.

[48] Sharma B. K. The Indian species of the genus Brachionus (Eurotatoria: Monogononta: Brachionidae). Hydrobilogia, 1983, 104, pp 3139.

[49] Kumar Pramod, Wanganeo A, Wanganeo R. and Sonaullah Fozia. Seasonal variations in Zooplankton Diversity of Railway Pond, Sasaram, Bihar. International Journal of Environmental Sciences. 2011, Vol. 2, No 2.

[50] Saxena D.N. and Sharma S.P. Zooplankton fauna of some lentic water bodies of Gwalior.I, Govind sagar, Ehanattri tank, Sawarkar sarover and Matsya sarover. Env. India. 1981, 4:13-17.

[51] Subbamma D. V. Plankton of a temple pond near Machili Patnam, Andhra Pradesh. J. Aqua. Biol., 1992, 7(1 \& 2):17-21.

[52] Pejaver M. K. and Somani V. Crustacean Zooplankton of Lake Masunda, Thane. Journal of Aquatic Biology, 2004, 19 (1): 57-60.

[53] Deevey E. S., Deevey Jr. G. B. and M. Brenner. Structure of zooplankton communities in the Peten Lake, District Guatemala. In W. C. Kerfoot (ed.), Evolution and Ecology of Zooplankton Communities. 1980, Pp. 669-678. University Press of New England, Hanover, NH.

[54] Elmore J. L. Factors influen cing Diaptomus distributions: An experimental study in subtropical Florida. Limnology and Oceanography, 1983, 28: 522-532.

[55] Lee C. E. and Bell M. A. Causes and consequences of recent freshwater invasions by saltwater animals. Trends in Ecology \& Evolution, 1999, 14: 284-288.

[56] Reid J. W. Arctodiaptomus dorsalis (Marsh): A Case History of Copep od Dispersal. Banisteria, 2007, Number 30, pp 3-18.

[57] Ayoade A. A., Agarwal N. K. and Chandola- Saklani A. Changes in Physicochemical Features and Plankton of Two Regulated High Altitude Rivers Garhwal Himalaya, India. European Journal of Scientific Research. 2009. 